\title{
Effectiveness of Health Education Using Leaflets in Fertile Age Women Against Knowledge About Tuberclosis in the Work Area of Tanjung Rejo Public Health Center Percut Deli Serdang in 2019
}

\author{
Efendi Sianturi ${ }^{1}$, Biner Situmorang ${ }^{2}$, Panigoran Siburian ${ }^{3}$ \\ Poltekkes Kemenkes Medan ${ }^{1}$, Universitas Negeri Medan ${ }^{2}$, Universitas \\ Sumatera Utara ${ }^{3}$ \\ e-mail : affila75@ymail.com
}

\begin{abstract}
Effectiveness of Health Education using Leaflets on Reproductive Age Women on Knowledge of TB in Tanjung Rejo Percut Sei Tuan Health Center in 2019. This study was used Pre-experimental research with the design of One Group Prestest-Posttest design. This research was conducted during January 2019 until May 2019. And the instruments used in this study were questionnaires and leaflets. The sample in this study were 40 women who had a productive age (20-45 years). From the results of the study it was found that the knowledge level of the respondents before being given penyluhan majority was in the Less category as many as 26 respondents $(65.0 \%)$; Knowledge of respondents after being given counseling became a sufficient majority category of 8 respondents $(20.0 \%)$, and after counseling and the results were tested by paired T-test samples T-test was obtained sig 2 tailed at 0,000 ( $\mathrm{p}$ value) $<0.05$ there was effectiveness of health education in women of childbearing age to knowledge about tuberculosis in the Tanjung Rrejo Deli Serdang Health Center area in 2019.
\end{abstract}

Keywords: education, health, leafleat, woman, age, fertile, tuberculosis

\section{Introduction}

Health is very important and valuable for all living things in the world, as well as health for women of childbearing age (WCA). WCA is a woman whose reproductive organs function well between the ages of 20-45 (Wahid Iqbal, 2014). Reproductive health in women is one of the things that are very important and a common concern because female reproductive organs are a tool as a successor to the offspring, for that it must be protected from various diseases. In this digital era, it is very important to pay attention to health, including tuberculosis. Tuberculosis is prevalent in the community given the increase in air pollution and environmental pollution which results in an increase in the number of non-adherent Tuberculosis participants.

This increase is due to the fact that some people are not aware of the presence of pulmonary TB sufferers around their homes. Tuberculosis is an infectious disease caused by the bacterium mycobacterium tuberculosis (TB) lung where most of the lung organs attack but do not rule out the possibility of attacking other organs. 
TB is transmitted by patients with smear (+) TB through the air when coughing or sneezing in the form of sputum sparks. Some factors that cause transmission of pulmonary TB are education, work, home condition, smoking habits and physical contact with patients. Based on the WHO report in 2013, Indonesia ranks third in cases of tuberculosis sufferers after the Indian and Chinese countries, with a large number of 700 thousand cases. The highest pulmonary tuberculosis patients are in the productive age, which is 15-50 years old, around 75\%. In 2015 the number of Tuberculosis cases in Indonesia was 330,910 cases, an increase compared to 2014 which amounted to 324,539 cases (Republic of Indonesia's Ministry of Health, 2016). The number of new cases of TB in Indonesia has increased to 420,994 cases in 2017 (the Ministry of Health's Republic of Indonesia's 2017 data and information center 2017) which has an impact on cases of death. The mortality and morbidity caused by Mycobacterium tuberculosis is also high. In 2009, 1.7 million people died of TB, which was 600,000 and among them were productive women. while there were 9.4 million new cases of TB, including 3.3 million women. So it can be concluded that a third of the world's population has been infected with TB and of these victims most TB patients are women of productive age. In order to minimize the risk of Tuberculosis infection in health care facilities and preventive measures and control of transmission of tuberculosis infection must be carried out effectively. The main purpose of preventing and controlling tuberculosis infection is early detection, as soon as possible and preventing other people from being infected with tuberculosis (RI Ministry of Health 2014). Research conducted by Nelly Marissa (2014) in July 2011 to June 2012 there were 19 smear (+) TB patients in the Darul Imarah Health Center working area. Most pulmonary TB patients are young with ages between 20 and 30 years. Most of the male pulmonary TB sufferers who have been diagnosed for the past 6 months. While Yuwana Hesti (2016) conducted research in the same field, where respondents in this study were all sufferers who were positive for pulmonary tuberculosis and underwent treatment in 2015 with a sample of 23 sufferers. The results of the study found that out of 23 respondents, 18 or equivalent to $78.26 \%$ were women. Unlike Puteri Febriana (2015) from her research at Koming Health Center, the results of the study showed that most of the respondents in low education were 33 people $(61.7 \%)$ people, the employment status worked as many as 48 people $(80 \%)$, as low as many 44 people $(73.3 \%)$ and less knowledge about 32 people $(53.3 \%)$ and positive attitudes as many as 36 people $(60 \%)$. From a preliminary survey conducted by researchers of one of the pulmonary TB sufferers who were waiting in line for taking drugs at a drug store, they admitted that 2 out of 4 family members were positive for pulmonary TB including themselves. Patients do not know how to prevent transmission to the family so there is no difference in eating equipment in the family. This fact shows that there is still a low level of public knowledge about pulmonary TB, especially in families who live in villages and work as farmers. From the above explanation, the authors are interested in conducting research on the Effectiveness of Health Education using leaflets in women of childbearing age on knowledge about TB in Percut Sei Tuan's Tanjung Rejo Health Center. 


\section{LITERATURE REVIEW}

\section{Women of Childbearing Age (WCA)}

According to Mubarak Wahid Iqbal (2014) what is meant by WCA is a woman whose reproductive organs function well between the ages of 20-45 (from the first menstruation to menopause). Reproductive health in women is one of the things that are very important and a common concern because female reproductive organs are a tool as a successor to the offspring, for that it must be protected from various diseases. Calculation of the fertile period using the calendar system is a natural or scientific method used only if a woman has a regular menstrual cycle. The calculation of fertility is based on ovulation on the 14th day of upcoming menstruation and minus 2 days because sperm can live as long as 48 hours after ejaculation and added 2 days because the egg can live 24 hours after ovulation.

\section{Health Education}

Education is basically all planned efforts to influence, provide protection and assistance so that participants have the ability to behave as expected. Education can also be said as a process of personal maturation. In addition, education is a process of guidance and demands to achieve certain goals and there appears to be changes in the participants. (Triwibowo, C, and Mitha, 2015)

Health education is a dynamic process of behavior change, with the aim of changing human behavior including components of knowledge, attitudes, or actions related to the purpose of healthy life both individually, in groups, and in society, and using existing and appropriate health care facilities in Triwibowo, C, and Mitha, 2015)

Thus, that health education can be interpreted as providing information, instruction or increasing understanding related to health. Health education covers the types of education related to potential health, how health potential can be achieved or related to how to avoid certain disease problems.

The principle of health education that needs to be understood is:

- Health education is not only a lesson in class, but it is a collection of experiences anywhere and anytime as long as it can influence the knowledge of attitudes and habits of educational goals

- Health education cannot be easily given by someone to someone else, because ultimately the education target itself can change its habits and behavior itself

- That what educators must do is to create individual, family, group and community goals that can change their own attitudes and behavior.

- Health education is said to be successful if the education goals (individuals, families, groups and communities) have changed their attitudes and behavior according to their intended goals (Triwibowo, C, and Mitha, 2015) 
The goals of health education according to Chayatin, N and Wahit Iqbal (2009) are:

- Making health something valuable in the community. Therefore, health education is responsible for directing healthy ways of life to become the daily habits of the community

- Helping individuals to be able to independently or in groups hold activities to achieve healthy living goals

- Encourage the development and use of appropriate health services. The use of existing service advice is sometimes carried out excessively or on the contrary on the condition of illness, it does not use the existing health facilities properly.

\section{Factors that influence Knowledge}

Wawan (2014) argues that the factors that influence knowledge are as follows:

a. Internal factors

- Education

Education means that the guidance given by someone to the development of other people leads to certain ideals that determine humans to do and fill life to achieve safety and happiness.

- Job

Working/job is a bad thing that must be done especially to support his life and family life.

- Age Age is the age of individuals starting from birth to birthday.

b. External factors

- Environmental factor

According to Ann. Mariner quoted from Nursalam is an environment that is all conditions that exist around humans and their influence that can affect the development and behavior of people or groups.

- Socio-cultural

The socio-cultural system that exists in society can influence the attitude of receiving information.

\section{Tuberculosis (TB)}

Tuberculosis is a contagious infectious disease caused by tuberculosis mycobacterium. These germs can attack anyone not except men, old men, young, rich and poor and everywhere (syafrudin, et al 2011)

TB must be treated quickly. Until now the pulmonary TB prevention program has not been able to reach all existing Puskesmas. This is due to the absence of uniformity of treatment and the reporting system of reporting in all health service units, both government and the private sector, so that all parties involved in eradicating TB are needed. In TB control, there are 2 targets, namely (soekidjo notoatmodjo 2011): 
- Long-term goals: Decide the chain of transmission so that pulmonary TB disease is no longer a public health problem in Indonesia

- Short-term goals: Achieving healing at least $85 \%$ of new positive patients found; achieving the coverage of all sufferers' discoveries in stages; Prevention of TB drug resistance in the community; and Reducing human sufferers due to TB disease

To achieve these objectives activities carried out in tackling tuberculosis include:

- Component of diagnosis

- Detect patients in polyclinic

- Laboratory diagnosis; Component of treatment and Adequate and appropriate treatment

- Track patients who fail to treat 2 days

- Extension to TB patients and the community

\section{RESEARCH METHODS}

The type of research used is Pre-experimental research with the design of the One Group Prestest-Posttest design. Where in the design of this study was carried out by giving prestest first before health education was conducted using leaflets. After being given health education, then posttest was conducted (Hidayat 2014).

\begin{tabular}{|l|l|l|}
\hline Q1 & X & Q2 \\
\hline
\end{tabular}

Information :

Q1: Prestest is given before health education about TB

Q2: Posttest is given after health education about TB

$\mathrm{X}$ : Providing health education using leaflets

The location of this study was conducted in the Work Area of Tanjung Rejo Sei Tuan Percut Deli Serdang Health Center in 2019. This research was conducted during January 2019 until May 2019. And the instruments used in this study were questionnaires and leaflets.

\section{RESULTS AND DISCUSSION}

\section{Results}

The results of this study were obtained from the sampling of data carried out for 4 weeks with the number of respondents as many as 40 women of the most fertile age of fertile tuberculosis. The presentation of data analysis in this study is described as follows: 
Univariate Data Analysis

After conducting research on the effectiveness of health education using leaflets on women of childbearing age on knowledge of tuberculosis in Tanjung Rejo Deli Serdang health center in 2019 as follows:

Table 1. Age Frequency Distribution, Education, Employment Status for Fertile Women Against Knowledge About TB

\begin{tabular}{|c|c|c|c|}
\hline Characteristics & Category & $\mathrm{F}$ & $\%$ \\
\hline \multirow{3}{*}{ Ages } & 20-30 year & 21 & 52.5 \\
\hline & $31-40$ year & 13 & 32.5 \\
\hline & $41-50$ year & 6 & 15.0 \\
\hline \multicolumn{2}{|c|}{ Total } & 40 & 100.0 \\
\hline \multirow{3}{*}{ Education } & SMP & 5 & 12.5 \\
\hline & SMA & 27 & 67.5 \\
\hline & D1-S1 & 8 & 20.0 \\
\hline \multicolumn{2}{|c|}{ Total } & 40 & 100.0 \\
\hline \multirow{5}{*}{ Job } & Motherhouse & 24 & 60.0 \\
\hline & Enterprenour & 3 & 7.5 \\
\hline & Employee & 8 & 20.0 \\
\hline & Official & 2 & 5.0 \\
\hline & Farmer & 3 & 7.5 \\
\hline \multicolumn{2}{|c|}{ Total } & 40 & \\
\hline
\end{tabular}

Based on the table above, some women of childbearing age who were respondents to this study were aged 20-30 years as many as 21 people $(52.5 \%)$. Most of the education respondents had high school education as many as 27 people (67.5\%). Most of the respondents work as IRT as many as 24 people (60.0\%)

Table 2. Distribution Table of Respondents' Knowledge Frequency Before health education and health education are conducted

\begin{tabular}{|c|c|c|}
\hline Before health education & F & $\%$ \\
\hline Well & 10 & 25.0 \\
Enough & 4 & 10.0 \\
Less & 26 & 65.0 \\
\hline Total & 40 & 100.00 \\
\hline After health education & $\mathrm{F}$ & $\%$ \\
\hline Well & 27 & 67.5 \\
Enough & 8 & 20.0 \\
Less & 5 & 12.5 \\
\hline Total & 40 & 100.0 \\
\hline
\end{tabular}

Based on the table above Frequency Before health education can be seen that from 40 respondents, the majority had Less Knowledge as many as 26 people (65.0\%). Most 
health education after health education can be seen that of the 40 respondents, the majority have good knowledge as many as 27 people (67.5\%).After univariate analysis, the results of the study were carried out by bivariate analysis, namely by using the $\mathrm{T}$ test. The $\mathrm{T}$ test was conducted to find out the average paired data or differences in the data of the two sample groups that are related to each other. Then the following results are obtained:

Table 3. Table of average values of respondents' answers

\begin{tabular}{|l|c|c|}
\hline Result & Prestest & Posttest \\
\hline Average & 24.05 & 31.77 \\
\hline
\end{tabular}

From the results of the analysis of the prestest and posttest average values, the respondents had a more significant average after health education where the previous average health education was 24.05 and after health education 31.77

\section{Discussion \\ Health Education}

According to Maryam (2011) Health Education is an activity or needs to convey health messages to the community, groups, or individuals in order to obtain better health knowledge.Based on the results of table 4.1, the majority of respondents' education is high school, amounting to 27 people (67.5\%), D1-S1 as many as 8 people (20.0) and junior high school education as many as 5 people (12.5\%). According to the researchers' assumption that health education has a significant influence by providing health education can change or influence a person's mindset from those who do not know to know. As after being given health education they become aware of the causes of TB disease, prevention and transmission of tuberculosis, so by providing health education can prevent the rate of increase in TB disease in the community

\section{Knowledge}

In the explanation of the results of table 4.4, the results of prior (prestest) knowledge of 24.05 and the results of knowledge after (posttest) were obtained 31.77 occurrences of increase, that respondents' knowledge about tuberculosis changed after being given health education. Increased knowledge can lead to changes in perceptions and habits of people because from experience and research it turns out that behavior based on knowledge will be better to last longer than not based on knowledge (Notomodjo 2013).The results of the study also supported by the research conducted by Daniel Tolossa (2014) say that the low level of knowledge about TB can affect patients' health seeking behavior and maintain transmission of internal diseases in 410 people suffering from tuberculosis. 316 people $(79 \%)$ stated that they knew that TB needed regular treatment, prevent transmission, while those who did not have education (illiteracy) as many as 94 people stated that they did not know about tuberculosis. 
According to the previous assumptions (Ermalynda Sukmawati 2014) about the Effectiveness of Health Extension on Knowledge of Tuberculosis Patients, the average knowledge of patients before and after the quasi-experimental group showed $\mathrm{p}(0.006<0.05)$ means that there was a significant difference between the patient's knowledge before and after giving health counseling about tuberculosis. While in the control group showed $p$ value $(0.98>0.05)$ meaning that there was no significant difference between the patient's knowledge of TB before and without being given health education about TB. while from the independent test, the results show $\mathrm{p}$ value $(0.000)<(0.05)$ this means that there is a significant difference between the knowledge of tuberculosis in the experimental group and the control group after being given counseling about tuberculosis, so it can be concluded that the provision of health education about TB is effective in improving knowledge about tuberculosis.

According to the assumption of the results of this study that the knowledge of respondents before counseling was seen a significant difference with respondents after being given counseling. This can be seen from the significant results for the average value of knowledge before being given counseling and after being given counseling. In theory, Notoatmodjo (2012) says that education is directly related to one's knowledge, so that the higher the education, the better one's knowledge is expected. In accordance with the theory (Wawan, et al 2017) knowledge (knowledge) is the result of knowing and this happens after someone does sensing a certain object. Sensing occurs through the five human senses, namely the senses of vision, hearing, smell, taste and touch.According to the Author's Assumption, Knowledge can be improved through print media or electronic media. So when we hold counseling we recommend that you use the media. Media leaflets can also increase one's knowledge because there are explanations in accordance with the material presented. So that the results of this study that the knowledge of respondents before counseling shows a significant difference with respondents after being given counseling. This can be seen from the significant results for the average value of knowledge before being given counseling and after being given counseling.

\section{Effects of WUS Knowledge Health Education}

Based on table 4.2 the frequency distribution of knowledge of women of childbearing age after being given counseling, good knowledgeable mothers as many as 27 respondents (67.5\%): SMA, enough as many as 8 respondents $(20.0 \%)$ : D1-S1, less than 5 respondents (12.5\%): Middle School . According to Wardana's 2010 theory, it turns out that education has an influence on the knowledge of respondents, the higher the level of education, the wider the level of insight and knowledge of a person.

In this study in accordance with the theory (Effendy, 2013), health education can change one's mindset, attitudes, and knowledge. Many media in counseling can be used. One's knowledge can change to a better one when someone gets education from someone else, for example through health education / counseling using the leaflet, one of which is by using a leaflet. Leaflet is a tool for delivering health promotion through viewing and hearing aids ( Wulandari 2007). This research is in line with the research conducted by Daniel Tolossa (2014) saying that the low level of knowledge 
about TB can affect patients' health seeking behavior and maintain transmission of internal diseases in 410 people who suffer from tuberculosis. 316 people (79\%) stated that they knew that TB needed regular treatment, prevent transmission, while those who did not have education (illiteracy) as many as 94 people stated that they did not know about tuberculosis. One of the factors that influence knowledge is education. The higher the level of education of a person influences knowledge. Likewise knowledge about prevention of transmission of tuberculosis (Tresnayanti 2015).

According to the researchers' assumptions from the results of this study that health education provided using leaflets has a significant effect so that in this study obtained the Effectiveness of Health Education on Fertile Age Women Against Knowledge About TB in Tanjung Rejo Deli Serdang Public Health Center in 2019. Data were analyzed using paired sample test with $\alpha=0.05$. the results of this study indicate that there is a difference in the knowledge of respondents before being given health education and after being given health education that is equal to ( $\mathrm{p}$ value $=0.000$ ). with these results indicate that there is Effectiveness of Health Education in Fertile Age Women Against Knowledge About TB in Tanjung Rejo Deli Serdang Health Center in 2019. Health education using leaflets can have a significant effect so that there appears to be a difference in the pre test and post test. So that the difference can be seen from the level of knowledge of respondents about TB knowledge in the Tanjung Rejo Deli Serdang Health Center in 2019.

\section{CONCLUSIONS AND RECOMMENDATIONS}

Based on the results of the research described in the previous chapter, the following conclusions can be drawn.

1. Knowledge of the respondents Before being given majority counseling Less than 26 respondents $(65.0 \%)$

2. Knowledge of respondents After being given majority counseling, there were 8 respondents $(20.0 \%)$

3. The effectiveness of health education in women of childbearing age on knowledge about tuberculosis in the TanjungRrejo Deli Serdang Community Health Center area in 2019 after being given counseling with the results of the Ttest paired T-test results obtained at 2 tailed for 0,000 ( $\mathrm{p}$ value) $<0.05$

Based on the conclusions of the results of the above research, the suggestions that can be put forward are as follows.

\section{- For Puskesmas}

The results of this study can provide information and can be used as a guide for Puskesmas to continue to provide health education and improve work programs related to pulmonary $\mathrm{TB}$ which are used as the effectiveness of health education 


\section{- For Midwifery Education}

The results of this study can be used as an additional reference for increasing the knowledge and insights of midwifery students about the effectiveness of health education using leaflets on the knowledge of TB in tanjung rejo puskesmas precut sei tuan deli serdang

- Share research

Can add insight and knowledge about the benefits of the effectiveness of health education in women of childbearing age on knowledge about TB

\section{References}

Mubarak, Wahid Iqbal. 2014. Public health science concepts and applications in midwifery. Salemba Medika: Jakarta.

Nur, A and Marissa N.2014. description of mycobacterium tuberclosis infection in household members of pulmonary TB patients.

Nasir and et.all. 2014. Health research methodology textbooks. Nuha Medika .: Yogyakarta

Tribowo, C and Mitha. Pusphandani. 2015. An introduction to basic public health sciences. Nuha Medika: Yogyakarta.

Syafrudin and et.all. 2011. Health education for adolescents, families, the elderly and the community. Trans Info Media: Jakarta.

Notoatmodjo, S. 2007. Health science and arts community. Rineka Cipta.:Jakarta.

Syukur, S 2016. Factors related to the incidence of pulmonary tuberculosis in the work area of Bolangtang health center.

Sukmawati, E. 2017. Effectiveness of health education on knowledge of tuberculosis patient care.

Sukmawati, Ermalynda.2017. Effectiveness of health education on knowledge of tuberculosis patient care.

Sukana, B and et al. 2003. The effect of counseling on TB patient knowledge in Tangerang District.

Tribowo, C and Mitha. Pusphandani. 2015. An introduction to basic public health sciences. Nuha Medika: Yogyakarta. 